\title{
FEUERBACH E A FUNDAÇÃO SENSÍVEL DA FILOSOFIA: IMEDIATIDADE E MEDIAÇÃO NA RELAÇÃO EU-TU
}

\author{
João Emiliano Fortaleza de Aquino* \\ emiliano.aquino@yahoo.com.br
}

Para Diogo. ... se me falta o amor, nada sou.

$(1 \mathrm{Co}, 13: 2)$

RESUMO Este artigo se propõe a apresentar a formulação feuerbachiana do fundamento sensivel do pensamento, buscando mostrar que nesse empreendimento Feuerbach: [1] toma como base uma teoria da objetivação, inseparável de uma teoria do homem como essência-gênero (Gattungswesen); [2] formula uma interpretação do desenvolvimento moderno da filosofia ao qual sua proposta filosófica seria imanente e do qual seria o resultado necessário; e [3] chega a formular as bases de uma nova posição ética, no plexo Eu-Tu. Desse modo, sua posição ontológica, ao reivindicar o sensivel como o verdadeiro, não se constitui num imediatismo, pois o sensivel ai apresentado é ele mesmo mediado pela existência genérica dos homens.

Palavras-chave Sensibilidade, essência-gênero, Eu-Tu.

ABSTRACT This paper intends to present the Feuerbachian formulation of the sensitive basis of thought, attempting to show that, for such enterprise, Feuerbach: [1] takes as its foundation a theory of objectification,

* Doutor em Filosofia, Professor da Universidade Estadual do Ceará (UECE). Artigo recebido em 12/09/2012 e aprovado em 15/06/2013. 
inseparable from a theory of humans as essence-species (Gattungswesen); [2] formulates an interpretation of the modern development of philosophy, from which his philosophical proposal would be immanent and of which it would be the necessary result; and [3] ends up formulating the basis of a new ethical position within the I-You plexus. Thus, his ontological position whereby he claims that that which is sensitive is that which is true does not constitute immediatism because such sensitivity is, itself, mediated by the generic existence of humanity.

Keywords Sensitivity, species-being, I-You.

\section{Infinitude genérica e finitude do indivíduo}

A concepção feuerbachiana da objetivação (Vergegenständlichung) retoma, com uma certa distância e com a necessária inversão de fundamento, a concepção hegeliana a esse respeito e, assim como essa, inclui em si a categoria da exteriorização (Entäusserung). ${ }^{1}$ No que diz respeito a Feuerbach, sua teoria da objetivação se relaciona diretamente com sua concepção do homem como essência-gênero (Gattungswesen), sendo, por isso mesmo, a base de sua concepção da essência da religião e do cristianismo. O homem é, para Feuerbach, a única essência que tem como objeto para si seu gênero ou sua essentidade (Wesenheit). ${ }^{2}$ Falar da essência genérica humana é dizer das essentidades que a constituem enquanto tal, isto é, do coração (sensibilidade, paixão, amor), da vontade (querer) e da razão (pensamento). Essas essentidades não são propriedades que o homem possui, mas, bem distintamente, são as determinações constitutivas da essência genérica que ele é. ${ }^{3}$

1 Não é o caso aqui de apresentar a concepção hegeliana da objetivação e da exteriorização, algo que, em termos sistemáticos, é central ao movimento especulativo do conceito, tanto em sua estrutura interna quanto em seu movimento de efetivação reflexa. Ele se encontra, portanto, não apenas no clássico capítulo VI da "Fenomenologia do espírito", mas, principalmente, nos parágrafos da pequena e da grande lógica nos quais Hegel expõe a estrutura especulativa do conceito (universalidade, particularidade e singularidade), bem como seu transcrescimento especulativo em ideia (conceito, objeto, ideia).

2 Feuerbach, em "A essência do cristianismo", parte da afirmação de que o homem é a única essência que tem consciência no sentido rigoroso do termo, justamente porque tem consciência de sua essência enquanto gênero. Essência, gênero e consciência são, portanto, determinações inseparáveis. É porque tem a consciência de si enquanto gênero que a própria consciência humana tem a forma da genericidade, podendo, assim, ter consciência genérica de outras essências, o que significa dizer que lhe é possível fazer ciência. $\mathrm{O}$ conhecimento científico se funda antropologicamente na própria essência genérica do homem, da qual é constitutiva a consciência.

3 Uma leitura atenciosa de Feuerbach indica que, ao se referir à essência, este autor não a toma no sentido tradicional de uma categoria relativa, embora contrária, à aparência. Numa proximidade de Spinoza, Feuerbach concebe a essência no mesmo sentido do ón grego, isto é, tão simplesmente, como uma 
Ora, essas essentidades constitutivas do gênero humano possuem objetos que não são senão suas próprias objetivações (isto é, as objetivações dessas essentidades genéricas). No dizer de Feuerbach, "o objeto com o qual o sujeito se relaciona essencial e necessariamente nada mais é que a essência própria, mas objetiva deste sujeito". "Assim, a razão tem como objeto o próprio pensamento ou razão, justamente como, na ciência ou na filosofia, se trata de tematizar a razão da coisa, tematização na qual o pensamento ou razão não tem nem pode ter por objeto senão o que lhe é próprio (conceituações, definições, leis, tendências etc. abstratas, suprassensíveis, ideadas), ainda que existente fora do pensamento ou da razão (portanto, existente na coisa). Rigorosamente o mesmo ocorreria, segundo este autor, com a vontade e o amor. A vontade quer, tão simplesmente; o que significa que seu objeto é o querer, ou que certo objeto é, como o reconhece a linguagem comum, objeto do querer ou $d a$ vontade. $\mathrm{O}$ amor ama, seu objeto sendo nada mais que o próprio amor, enquanto objeto do amor. Assim, os objetos da razão, da vontade e do amor o são enquanto objetivações da razão, da vontade e do amor, isto é, exteriorizações dessas essentidades genéricas, nas quais estas se fazem objetos para si mesmos; neles se encontram objetivadas, ou neles constituem sua objetividade, as próprias essentidades do gênero.

Assim, meus objetos confirmam o que sou; e, antes de tudo, que sou, simplesmente. "O homem nada é sem objeto". ${ }^{5}$ Ora, por objeto traduz-se aqui o termo alemão Gegenstand, o que está contra ou diante de. A objetivação implica, portanto, uma exteriorização. Os objetos genéricos são exteriorizações das essentidades genéricas em objetos, objetos estes que são exteriores não ao gênero enquanto tal, mas aos indivíduos que somente os podem experimentar

existência, como um fato de ser, ainda que essência seja sempre dita por ele num âmbito genérico, em diferença com o pensador holandês, que a busca pensar sempre como essência singular. É por isso que, para Feuerbach, as essentidades não se ajuntam à essência genérica do homem como acidentes (ou concomitantes), no sentido da metafísica tradicional, mas, antes, a constituem essencialmente. Para a crítica feuerbachiana da oposição essência-aparência, ver "Princípios da filosofia do futuro". Tradução portuguesa de Adriana Veríssimo Serrão. Lisboa: Centro de Filosofia da Universidade de Lisboa, 2005c, § 43, p. 144; "Grundsätze der Philosophie der Zukunft". In: Gesammelte Werke. B. 9: Kleine Schriften II (1839-1846). Berlin: Akademie-Verlag, 1970c, p. 325. (Daqui em diante, indico as referências dessa última obra pelas abreviaturas $P F F$ e GPZ, não repetindo os $\S \S$, pois são os mesmos nas duas edições, limitandome, nesses casos, a indicar a página da edição alemã; quando julgar necessário, modifico a tradução. Nesse trabalho de cotejamento, utilizo eventualmente a tradução de Artur Morão - Lisboa: Edições 70, 2002).

4 Feuerbach, L. "A essência do cristianismo". Tradução brasileira de José da Silva Brandão. Petrópolis, RJ: Vozes, 2007, p. 37, tradução levemente modificada; "Das Wesen des Christentums". Stuttgart: Philipp Reclam, 2005a, p. 41. (Estas duas edições consultadas são conforme a terceira edição alemã de 1849 e são indicadas, doravante, pelas abreviaturas $E C$ e WC, modificada a tradução brasileira quando considerar adequado).

$5 E C$, p. $37 ; W C$, p. 41. 
na forma de uma exterioridade individual, embora não o possam fazer senão enquanto partes de um gênero cujas essentidades neles se objetivam. Apenas por fazer-se objeto de si e para si na exterioridade, o homem pode ter consciência de sua própria essência (ou de suas essentidades genéricas). É preciso observar que este 'fazer-se objeto' exterior não significa, em Feuerbach, uma atividade. A inversão de fundamento operada por Feuerbach com relação a Hegel traz consigo esta consequência em sua teoria da objetivação (e, portanto, da exteriorização): diferentemente de Hegel, para quem a posição do absoluto como sujeito significa que este, desde sua forma conceitual, é ativo, realiza uma atividade cujo resultado é seu próprio desenvolvimento imanente, Feuerbach conscientemente compreende o fundamento sensível do pensar como passivo. Trata-se da capacidade de afetar e ser afetado, capacidade esta dada pela relação sensível-afetiva dos entes naturais (entre os quais, os homens) uns com os outros. Assim, a objetivação não é uma atividade, mas uma recepção, uma Anschauung (intuição) dos objetos dos sentidos, da vontade e do pensar. A natureza passiva da sensibilidade determina e enforma as demais essentidades que se desenvolvem com base nela: "Só o amor, a admiração, a veneração, em suma, o afeto transformam o indivíduo em gênero", afirmaria Feuerbach dois anos de escrever "A essência do cristianismo". ${ }^{6}$ Desse modo, o objeto sensível me confirma como ser igualmente sensível, não porque ele é posto por uma atividade minha enquanto ser sensível, mas por minha passividade, pela qual sou capaz de ser afetado por um objeto que necessariamente existe fora de mim. É deste modo que minha essentidade sensível encontra-se objetivada: por minha receptividade do objeto sensível, só possível porque, sendo sensível, posso ser afetado por objetos igualmente sensíveis; e, desse modo, encontrome nele confirmado. "O que de um objeto nos tornamos conscientes para nós, por isso também sempre, nós nos tornamos igualmente conscientes de nossa própria essência; não podemos ocupar-nos (betätigen) de nada de outro sem nos ocuparmos de nós próprios". ${ }^{7}$

É por essa circularidade que as essentidades genéricas, enquanto genéricas, se apresentam como perfeitas (completas, vollkommen) e infinitas, pois têm objetos na medida em que se dão a si mesmos, neles tendo apenas a si próprias sob o modo da objetividade. Diz Feuerbach: "é impossível que sejamos conscientes da vontade, do sentimento e da razão como forças finitas, porque toda perfeição, toda força e essentidade é uma certificação 
e confirmação imediatas de si mesma". ${ }^{8}$ Em consequência, para Feuerbach o homem enquanto gênero é uma essência infinita, perfeita, distinto assim do homem enquanto indivíduo, no qual as essentidades genéricas, em si perfeitas, se manifestam imperfeitamente, pois parcialmente. A finitude é, portanto, de um ponto de vista genérico, própria do indivíduo, mas não do gênero. Na medida em que a religião e, seguindo-a, a filosofia tomam Deus ou o absoluto como infinito, contrastando-o com a pretensa finitude genérica do homem, expressam aí algo que é próprio à consciência religiosa: a objetivação da essência genérica (infinita) do homem numa outra essência, distinta e separada do homem, uma objetivação que, contudo, permanece velada na própria consciência religiosa. Em decorrência, o descompasso entre o gênero (infinito) e o indivíduo (finito) é transferido pela consciência religiosa (e filosófica) para o descompasso entre Deus (essência genérica humana objetivada exteriormente) e o homem (representado genericamente, e falsamente, na imperfeição e finitude próprias ao indivíduo). É nesse sentido que, em termos feuerbachianos, a afirmação positiva da infinitude genérica do homem só pode ser traduzida, em conformidade com os termos da tradição religiosa e filosófica, como uma escandalosa afirmação da positividade e da autossuficiência da finitude humana.

\section{A nova filosofia enquanto superação-realização da filosofia especulativa}

A indicação feuerbachiana de que "filosofia ou religião em geral, i.e., abstraindo-se de sua diferença específica, são idênticas" ${ }^{9}$ haveria necessariamente, com base ainda na tese de que "a religião [...] é o relacionamento do homem consigo mesmo [...] com sua essência", ${ }^{10}$ que resultar numa crítica imanente da filosofia moderna, especialmente a especulativa, conduzindo-se daí - se tivermos em vista os termos da própria tradição filosófica (mas não, como vimos, do próprio Feuerbach) - a uma fundamentação finitista e sensível de um novo pensamento filosófico. Por filosofia especulativa, Feuerbach entende aquela que, de Spinoza a Hegel, substitui a transcendência do divino por sua imanência ao mundo. ${ }^{11}$ Contudo, a crítica da filosofia especulativa não

$8 E C$, p. 39; WC, p. 43.

9 EC, p. $11 ; W C$, p. 6.

10 EC, p. 45; WC, p. 54.

11 Não mais falando da identidade entre filosofia e religião, mas entre filosofia e teologia, Feuerbach afirma que "o segredo da filosofia especulativa é a teologia", especificando e explicando em seguida que se refere à "teologia especulativa, a qual se distingue da teologia comum; ela muda para o aquém, isto é, 
se lhe impõe apenas por uma necessidade conceitual interna aos termos em que, nas duas principais obras que dedica a esse objeto (a saber, "A essência do cristianismo" e a "A essência da religião"), se desenvolve sua crítica do cristianismo e da religião em geral, mas, antes, por uma interpretação da sua época histórica, marcada tanto no âmbito religioso como no filosófico pela "negação" e "decadência" do cristianismo.

"O cristianismo", diz ele, "já não corresponde nem ao homem teórico, nem ao homem prático; já não satisfaz o espírito, nem sequer também satisfaz o coração, porque temos outros interesses para nosso coração diversos da beatitude celeste e eterna". ${ }^{12}$ Nessa interpretação histórica, a filosofia especulativa, em sua expressão especificamente hegeliana, "pertence ao período da decadência do cristianismo, da sua negação, mas que pretende ser ao mesmo tempo a sua posição". ${ }^{13}$ Essa correspondência histórica entre a negação prática e teórica do cristianismo por toda uma época e a filosofia hegeliana, que, contudo, tem a pretensão teórica de afirmá-lo (embora nas características que lhe são próprias no período de sua decadência), correspondência que não é apenas de contemporaneidade cronológica, mas antes de um sentido mais amplo e fundamental que caracteriza toda a época histórica, é retomada no primeiro dos "Princípios da filosofia do futuro" (1843) em termos filosófico-históricos mais amplos: "A tarefa da época moderna foi a efetivação (Verwerklichung) e humanização de Deus - a transformação e a dissolução [ou resolução (Auflösung)] da teologia na antropologia". ${ }^{14}$ Nesses termos, é toda a época histórica moderna que se caracteriza por uma relação prática e teórica de imanência ao mundo, experimentando-o em termos práticos e o representando em termos teóricos numa afirmação do terreno e humano, e mais decisivamente, do homem em sua infinitude genérica como essência positiva.

Se, em "A essência do cristianismo", Feuerbach tem por objeto específico principalmente a crítica da "filosofia da religião positiva ou da revelação", cuja experiência histórica se encontra "num arquivo de séculos há muito passados", no que chama de "épocas clássicas" do cristianismo, ${ }^{15}$ e não da "filosofia especulativa da religião que, como durante a escolástica, demonstra

presentifica, determina e realiza a essência divina, que a outra exilava para o além, por medo e estupidez" (Feuerbach, 2002a, p. 19, grifos do original, tradução levemente modificada; Feuerbach, 1970b, p. 243).

12 Feuerbach, 2002c, p. 14.

13 Ibidem, p. 15.

14 PFF, § 1, p. 102; GPZ, p. 265.

15 EC, p. 13; WC, p. 9. 
o articulus fidei definitivamente como uma verdade lógico-metafísica", ${ }^{16}$ algo diferente ocorre nos "Princípios da filosofia do futuro". Nestes, seu objeto é justamente a época moderna que, em seu conjunto prático e teórico (eo ipso, religioso e filosófico), realiza, pela afirmação prática e teórica do humano e mundano, uma negação de Deus e da religião, embora seja uma negação ainda incompleta e contraditória. No âmbito teórico, a filosofia especulativa nega Deus ao tomá-lo como imanente ao mundo, negando o Deus separado do cristianismo clássico; o mesmo faz o cristianismo moderno (protestantismo), embora não o faça assumindo no âmbito teórico (teológico) todas as consequências de sua postura prática: o cristianismo moderno nega o "Deus em si ou Deus como Deus [...] de um modo puramente prático", embora teoricamente (teologicamente) continue a pensar que Deus "é uma essência além, uma essência que naqueles dias somente lá no céu se torna objeto para o homem". ${ }^{17}$ É essa contradição entre prática e teoria no lado prático do cristianismo (isto é, na religião) que a filosofia especulativa (o lado teórico do cristianismo decadente) 'resolve' ao conceber o divino como imanente ao mundo, oferecendo teoricamente uma correspondência à prática cristã moderna de assunção positiva do mundo civil e jurídico terreno. ${ }^{18}$

Por isso, para Feuerbach, a filosofia especulativa é a verdadeira teologia do cristianismo (decadente) dos tempos modernos, uma teologia especulativa que expressa em termos conceituais a natureza divina do homem e de seu mundo social, reconhecida pela religião moderna apenas em termos práticos, mas não em termos teóricos. Contudo, como no âmbito prático ocorre com a religião, também no âmbito teórico a negação do Deus em si, transcendente, negação que se dá pela afirmação da imanência terrena do divino por parte da filosofia especulativa, é uma negação ainda contraditória em termos especificamente teóricos. Sua contradição se constitui não apenas do fato de que nela - e é isto o que a caracteriza enquanto especulativa - o homem em sua existência mundana e temporal é pensado como forma finita da infinitude

16 EC, p. 12; WC, p. 5.

17 PFF, § 3, p. 102; GPZ, p. 265-266.

18 Em sua "História da mais recente filosofia: de Bacon a Spinoza" (1833), Feuerbach afirma que todo novo princípio do mundo se expressa também como princípio religioso. É por isso que, quanto à época moderna, diz que "o protestantismo é o novo princípio, como este se expressa enquanto princípio religioso". Neste sentido, o protestantismo é "uma manifestação particular" do espírito de toda a época moderna, espírito que Feuerbach caracteriza como aquele "que produziu a vida burguesa livre, através do sentido prático do mundo, que embeleza e aprimora a vida inventiva rica de sentido, reconciliada com o presente, que eleva a autoconsciência do homem"; [...] "o mesmo e nenhum outro espírito, o espírito que se expressa no indivíduo como sentimento pessoal de independência e liberdade, que lhe dá a consciência ou sentimento da divindade inata à sua essência e através disso a potência, de nenhum modo externa, de reconhecer à consciência o poder definitivo (bindende Macht) de se decidir e determinar o que para ela deve ser o poder obrigatório (bindende Macht) da verdade" (Feuerbach, 1976, § 6, p. 17-18). 
absoluta de Deus, mas, tal como justamente (e principalmente) ocorre na filosofia hegeliana, o faz concebendo Deus como pensamento, razão: "A mais nova filosofia efetivou [hat... verwirklicht] e superou [aufgehoben] a essência divina separada e distinta da sensibilidade, do mundo, do homem - mas apenas no pensamento, na razão e, na verdade, numa razão igualmente separada e distinta da sensibilidade, do mundo, do homem". ${ }^{19}$

$\mathrm{Na}$ verdade, esses são dois aspectos inseparáveis, pois o movimento pelo qual a filosofia especulativa toma como sujeito o que na teologia teísta tradicional é o objeto do conhecimento (a saber, Deus) é, a rigor, o desenvolvimento racional da natureza mais íntima e própria de uma essência que, embora representada pela imaginação (na religião e na teologia tradicionais) no modo de um objeto sensível (pois separada e distinta do homem), é, ao mesmo tempo, pensada como espiritual, suprassensível. ${ }^{20}$ Ora, essa contradição da teologia teísta é resolvida pela filosofia especulativa, tout d'un coup, ao desenvolver como puramente racionais, isto é, como determinações do pensamento, aquelas propriedades divinas que, no teísmo, expressam Deus enquanto essência suprassensível, contudo exterior ao pensamento humano (e logo, segundo a argumentação de Feuerbach, sensível). Que Deus seja infinito, necessário, universal, imutável, eterno, autossubsistente, tal como o apresentara a teologia teísta, afirmam-se nessas determinações, porém, características próprias à razão, características que por si negam Deus enquanto essência sensível, portanto também enquanto essência separada e independente do pensamento e da razão do homem. Assim, é uma necessidade lógica que essas propriedades só possam afirmar-se enquanto suprassensíveis se se suprime a separação entre Deus e o mundo, tornando-os especularmente um só. Justamente isso o fez Spinoza, ao conceber Deus como substância, de cujos infinitos atributos (cada um dos quais infinito em seu gênero) conhecemos especulativamente, em nossa modalidade finita, a extensão e o pensamento; e também o fez Hegel, tomando porém o pensamento ou a razão como forma primeira do absoluto, que se desenvolve especulativamente na finitude da natureza e do espírito subjetivo e objetivo, e que se reencontra em sua própria infinitude nas formas do espírito absoluto, a saber, arte, religião e filosofia.

19 PFF, § 18, p. 121-122; GPZ, p. 293 - grifos do original.

20 "O teísta se representa Deus como uma essência pessoal, existente, fora da razão e exterior aos homens em geral - pensa enquanto sujeito sobre Deus enquanto objeto. Pensa Deus como uma essência que, segundo sua representação, é uma essência espiritual, não-sensível, mas que, segundo a existência, isto é, segundo a verdade, é uma essência sensível, pois a característica essencial de uma existência objetiva, de uma existência exterior ao pensamento ou à representação, é a sensibilidade" (PFF, § 7, p. 104-105; GPZ, p. 269 - grifos do original). 
Essa imanência do absoluto ao mundo, com cuja finitude o mesmo absoluto mantém uma relação especular, imanência que nega o Deus em si-e, portanto, o próprio Deus, pois que, para Feuerbach, "apenas Deus em si é propriamente Deus"21 -, é uma superação de Deus ainda contraditória, ou uma superação da religião ainda religiosa: ela repõe, ainda que de outra forma, a objetivação de uma essentidade genérica humana (neste caso, a razão, o pensamento) como essência existente fora da finitude do homem, ou melhor, existindo de uma forma não propriamente humana (pois não na finitude que, segundo os termos também de toda filosofia até então, é própria ao homem enquanto gênero). Se, no cristianismo clássico, Deus é imaginado como essência exterior, tal como qualquer objeto dos sentidos, é-o na mesma medida em que e porque Ele é representado como amor, sentimento, paixão; e, justamente assim, é a objetivação da essentidade mais fundamental do homem, aquela mesma com base na qual todo objeto, toda essência existente fora de mim, diante de mim, se torna possível, uma objetivação que, portanto, não nega Deus também como dotado de vontade e razão. Ora, o Deus sensível transcendente, enquanto objetivação humana, testemunha a condição sensível da existência humana, e, portanto, também a razão e a vontade como essentidades que têm objetos fora e diante do homem. Já o Deus imanente da filosofia especulativa hegeliana, ao conceber Deus ou o absoluto como primeiramente pensamento ou razão, tende também a reduzir o homem à razão, ao pensamento, tornando as demais essentidades humanas (a sensibilidade e a vontade) em propriedades objetivadas da razão; e assim o é na medida em que e porque o próprio homem e a natureza sensível da qual ele faz parte já são concebidos como objetivações finitas do absoluto, que em si e por si é, antes de tudo, pensamento, razão.

Ao passo em que realiza uma negação de Deus, enquanto objeto do amor, da vontade e da razão humanos, existindo fora do homem e do mundo, simplesmente o negando enquanto Deus, enquanto essência infinita exterior ao homem e à natureza em suas finitudes, a filosofia especulativa repõe Deus ou o absoluto como realidade sobre-humana, ou não especificamente humana, na forma de uma razão absoluta. Se não há mais separação e distinção radicais entre o pensamento divino e o humano, pois sua relação é o reflexo especular do infinito com sua expressão finita, é apenas na medida em que e porque, para Feuerbach, o próprio Deus, reduzido a pensamento, demonstrase uma objetivação unilateral do homem; e objetivação de uma única de suas essentidades genéricas: o pensamento. Justamente por isso trata-se, na 
filosofia especulativa, como de um outro modo no cristianismo moderno (protestantismo), de uma negação ainda contraditória de Deus e da religião. É essa contradição que a "nova filosofia", como Feuerbach nomeia a sua própria, tem por propósito resolver: ela reivindica para si uma imanência ao desenvolvimento mais geral da filosofia moderna, e especulativa em particular, propondo-se a levar à frente a afirmação positiva do homem, do mundo e da sensibilidade, libertando-se, contudo, da contradição em que nesse campo se enredam o protestantismo e a filosofia especulativa. Trata-se, neste caso, de um projeto filosófico assentado historicamente na "tarefa" já realizada prática e teoricamente pelo próprio mundo moderno, levando-a à radicalidade e às últimas consequências ao afirmar explicitamente e sem contradições aquele fundamento que a religião e a filosofia modernas afirmam implicitamente e com contradições. Em suas palavras:

A nova filosofia, segundo seu ponto de partida histórico, tem a mesma tarefa e posição perante a filosofia anterior que esta teve perante a teologia. A nova filosofia é a realização da hegeliana, da filosofia anterior em geral - mas uma realização que é ao mesmo tempo a negação e na verdade uma negação livre de contradição da mesma. ${ }^{22}$

\section{O ser enquanto sensível e enquanto objetivação genérica}

A realização-negação da filosofia especulativa, tendo um fundamento antropológico (a essência-gênero que o homem é), assume uma tese ontológica que lhe é central: o que-é é somente enquanto exterior ao pensamento. Isso quer dizer que, ao contrário da grande tradição filosófica, que, de Parmênides a Hegel, concebeu a identidade do ser com o pensar como critério da verdadeira realidade, para Feuerbach este critério passa a ser "o de que algo não é apenas pensado"; 23 ou ainda que: "Ser é o limite do pensar". ${ }^{24}$ É porque existe fora do pensamento que algo não existe apenas como objeto pensado por e para um sujeito, mas, justamente enquanto objeto para outro, é também um sujeito em si e por si mesmo, diante de e contraposto ao outro sujeito, não sendo redutível, portanto, à representação que dele este faça, mas que é, sim, capaz de opor-lhe resistência. "Ser é algo em que não eu sozinho, mas sim também os outros, sobretudo também o próprio objeto está implicado. Ser significa ser sujeito, 
quer dizer, ser por si [für sich]", ${ }^{25} \mathrm{Na}$ medida em que o ser é por si, algo que é pode demonstrar não ser o mesmo que a representação que dele o outro faça; e justamente assim se demonstra não ser o outro. Ora, o que pode resistir ao pensamento, o que é o outro do pensamento é somente a sensibilidade, e isto o assegurou em demasia a tradição filosófica, que, contudo, afirmou o pensamento como lugar do ser, numa postura de denegação do sensível. Par Feuerbach, trata-se justamente de, partindo dessa oposição feita pela própria tradição filosófica, afirmar o outro do pensamento, afirmar o sensível como lugar do ser e critério do que efetivamente é. Daí por que diga: “Apenas o sentido, apenas a intuição me dá algo enquanto sujeito". ${ }^{26}$ Com base nisso, é possível a afirmação mais geral, com a qual talvez se opere uma das maiores rupturas com a tradição filosófica, ruptura que, contudo, a reivindica criticamente: "O efetivo [Wirkliche] em sua efetividade ou enquanto efetivo é o efetivo enquanto objeto do sentido, é o sensível. Apenas uma essência sensível é uma essência verdadeira, efetiva, apenas a sensibilidade [é] verdade e efetividade". ${ }^{27}$ A tese da identidade ser e pensar, que, contudo, tomava o próprio pensar como o lugar a partir do qual e no qual essa mesma identidade se demonstrava real, é aqui invertida em sua consequência mais extrema: apenas o sensível, porque outro do pensamento (e, em consequência, não idêntico em si e por si à representação) pode, por isso mesmo, ser o critério, inclusive para o próprio pensar (embora antes de tudo para a própria sensibilidade), do que é em verdade e efetividade.

Entretanto, não encontramos nessa tese a afirmação simples da verdade enquanto imediatidade empírica. Não só a própria teoria feuerbachiana da objetivação, enquanto objetivação genérica, o impediria, mas também porque, em coerência com essa mesma teoria da objetivação, a lida humana com objetos é sempre uma lida imediata mediada pelo próprio gênero. Exatamente sobre isso diz Feuerbach: "Tudo é por isso sensivelmente perceptível, se não imediatamente, pelo menos mediatamente; se não com os sentidos rudes, brutos, pelo menos com os sentidos educados, instruídos; se não com os

$25 P F F, \S 25$, p. 129; GPZ, p. 304, grifos do original. Optei por verter für sich neste passo em "por si", e não em "para si", porque o objeto, o que tenho diante de mim, não necessariamente é para si, no sentido de ter-se a si mesmo como objeto, isto é, ter consciência; embora isso possa ocorrer se meu objeto for um outro homem, nessa tese ontológica mais geral Feuerbach se ocupa da objetividade sensível como um todo, isto é, de tudo aquilo que, não sendo eu mesmo, existe independente de mim, ou seja, existe por si próprio.

$26 P F F, \S 25$, p. 128; GPZ, p. 304 - grifos do original. Entenda-se: não enquanto eu sou sujeito (embora também o seja!), mas enquanto o próprio algo - que me é dado pela sensibilidade - é ele mesmo sujeito. Ele é sujeito, portanto, no sentido próximo do hypokeimenon aristotélico (por si), mas não necessariamente como sujeito no sentido da res cogitans cartesiana (para si).

27 PFF, § 32, p. 132; GPZ, p. 316 - grifos do original. 
olhos de anatomista ou de químico, pelo menos com os olhos de filósofo". ${ }^{28}$ Segundo Feuerbach, o empirismo tem razão em conceber os sentidos como fundamento de nossas ideias; contudo, diz ele, "esquece-se apenas de que o mais importante e mais essencial objeto dos sentidos do homem é o homem mesmo". ${ }^{29}$ Ao referir-se ao homem enquanto o mais essencial objeto dos sentidos humanos, Feuerbach aponta para o homem enquanto essência-gênero - e, logo, enquanto relação genérica que constitui a essência que sou. Sob o ponto de vista dessa interpretação, o célebre $§ 39$ dos "Princípios da filosofia do futuro" deve ser lido com cuidado. Lá Feuerbach afirma: "somente onde começa a sensibilidade cessa toda dúvida e toda disputa. O segredo do saber imediato é a sensibilidade". ${ }^{30}$ Porém, em seguida, ao buscar argumentar em favor dessa tese apoiando-se numa crítica da concepção especulativa (hegeliana) da mediação, afirma:

A verdade que se mediatiza é ainda a verdade enredada no seu contrário. Começa-se pela oposição; mas, em seguida, esta vem a ser superada [aufgehoben]. Se ela é, pois, algo a superar [Aufzuhebendes], algo a ser negado [zu Negierendes], por que devo eu começar por ela, por que não começar de preferência com sua negação ${ }^{31}$

Em outras palavras, a imediatidade aí reivindicada é uma segunda imediatidade, a imediatidade já produzida pela mediação, ou seja, uma imediatidade mediada. Deve-se partir já do resultado da negação, isto é, em linguagem hegeliana, da negação da negação, do resultado do processo mediativo, exatamente como, do ponto de vista da história da filosofia, a "nova filosofia" parte dos resultados e contradições do desenvolvimento da filosofia especulativa moderna.

É enquanto genericamente sensível que o homem pode ter objetos (da sensibilidade, da vontade, do pensamento), objetos que, enquanto são suas objetivações, não lhe são, contudo, redutíveis, pois, justamente enquanto objetos, diante dos quais o homem se posta passivamente, são também eles mesmos sujeitos em si e por si. E é assim porque, enquanto sensível, o homem pode ter diante de si um outro, tão simplesmente: um outro sensível, que, diante dele, o limitando e lhe resistindo, testemunha sobre si e sobre outros mais. Isso quer dizer que a natureza sensível (portanto, passiva) do homem é o que o põe diante de objetos e também diante de outros homens, de outros sujeitos, 
que são objetos para ele. Em outras palavras, porque é sensível o homem vive num mundo de objetos, que é também o mundo de outros homens, que, por sua vez, medeiam suas relações com a totalidade dos objetos possíveis. É por isso que, apenas enquanto essência-gênero - e, portanto, enquanto sensível -, o homem pode ter objetos diante de si: "A própria certeza da existência das outras coisas fora de mim é para mim mediada pela certeza da existência de um outro homem exterior a mim". ${ }^{32}$ É por isso que o reconhecimento ontológico do ser implica, nas palavras de Feuerbach, "não eu sozinho, mas sim também os outros". Se toda a efetividade é necessariamente exterior a mim e de mim independente, e por isso mesmo age sobre mim, sobre meus sentidos (e, por extensão, também sobre minha vontade e meu pensamento), minha própria autoatividade a propósito dessa efetividade encontra sempre nela um limite, uma resistência (e justamente porque, enquanto objeto, ela é sujeito, algo por si). Assim, a genericidade de toda objetivação, implícita já na própria existência de um objeto diante de mim, enquanto objetivação genérica, somente se explicita completamente em que toda objetividade diante de mim é mediada pela minha relação com um outro Eu: "O conceito do objeto não é originariamente senão o conceito de um outro Eu [...] por conseguinte, o conceito de objeto em geral é mediatizado pelo conceito do Tu, do eu objetivo". ${ }^{33}$

"Apenas essências sensíveis influenciam umas às outras", diz ainda Feuerbach. "Eu sou eu - para mim - e ao mesmo tempo $\mathrm{Tu}$ - para outro. Mas só o sou enquanto essência sensível". ${ }^{34}$ Assim, a natureza sensível das essências e, entre elas, dos homens é o que pode constituir e de fato constitui

32 PFF, § 42, p. 144; GPZ, p. 324.

33 PFF, § 33, p. 138; GPZ, p. 316 - grifos do original. Conforme sua concepção de objetivação (e exteriorização), a relação genérica não é, para Feuerbach, produzida por uma atividade, mas antes confirmada pela afecção. Por isso, partindo de sua própria concepção de práxis, Marx pode observar em Feuerbach uma concepção do gênero "como generalidade interior, muda, que liga naturalmente os indivíduos" (Marx, 1984, § 6, p. 109). A explicação para essa crítica de Marx pode ser encontrada já nos "Manuscritos" de 1844: "na elaboração do mundo objetivo [é que] o homem se confirma, em primeiro lugar e efetivamente, como ser genérico. Esta produção é a sua vida genérica objetiva” (Marx, 2004, p. 85). Mais à frente, Marx insiste sobre a natureza ativa da condição genérica do homem, "o que é possível apenas mediante a ação conjunta dos homens, somente enquanto resultado da história" (ibidem, p. 123). Assim, por não considerar a "atividade humana sensível, práxis" (Marx, 1984, § 1), porque "não toma o mundo sensível como atividade humana sensível prática” (ibidem, § 5), Feuerbach terminaria, segundo Marx, por "pressupor um indivíduo abstratamente - isoladamente - humano" (ibidem, § 6). Portanto, a relação Eu-Tu que ele enxerga não seria, para Marx, compreendida por Feuerbach como produto prático das próprias atividades humanas. Para o entendimento dessa crítica de Marx é indiferente o fato de Feuerbach afirmar ser o homem "essencialmente um ser dualista, um ser ativo e passivo, autônomo e dependente, autossuficiente e social, ou comunicativo, teorético e prático" ( $P F F$, § 58, p. 153; GPZ, p. 338); pois ativo ele o seria enquanto autônomo, autossuficiente e teorético, não conseguindo nesse âmbito superar a filosofia idealista, enquanto seria passivo (leidendes), como ser dependente, social e prático (sic) (o que Feuerbach entende por "prático" é a relação genérica, fundada na passividade, base justamente da linguagem, da comunicação).

34 PFF, § 33, p. 138; GPZ, p. 317. 
a relação do homem com a objetividade e, nela, com a alteridade genérica, a relação com outros homens. É por isso que Feuerbach afirma que, a "verdade [sendo] unicamente a totalidade da vida e da essência humanas" (portanto, na essência humana, a totalidade de suas essentidades), o "homem singular por si não possui em si a essência do homem nem enquanto ser moral, nem enquanto ser pensante": "A essência do homem está contida apenas na comunidade, na unidade do homem com o homem - uma unidade que, porém, se apara [stützt] apenas na realidade da distinção do Eu e do Tu". ${ }^{35}$ A nova filosofia, ao reinverter o fundamento idealista do pensamento para o ser sensível, reencontra não apenas a essentidade da sensibilidade como aquela a partir da qual a totalidade das essentidades genéricas pode ser reposta, mas também, e por essa via, reencontra a unidade afetiva (amorosa, sensível), teórica (do pensamento) e moral (da vontade) dos indivíduos com o seu gênero. Em "A essência do cristianismo", Feuerbach já havia afirmado que a "vida interior dos homens é a vida relacionada com o seu gênero, com sua essência". ${ }^{36}$ Daí por que, quando pensa, o homem "conversa, fala consigo mesmo", mas o faz porque - cumprindo o pensamento e a linguagem uma "função genérica" - o homem "é para si ao mesmo tempo Eu e Tu; ele pode se colocar no lugar do outro exatamente porque seu gênero, sua essência, não somente sua individualidade, é para ele objeto". ${ }^{37}$ É por isso que a nova filosofia, ao fundar-se no homem enquanto gênero e, portanto, ao fazê-lo, na natureza e na sensibilidade, redescobre - na função genérica da linguagem e do pensamento - o filósofo como "homem com homens" 38 e a dialética como "diálogo entre Eu e Tu". ${ }^{39}$

Trata-se aí de uma legitimação ontológica do sensível enquanto legitimação antropológica, humano-genérica. A sensibilidade, sendo uma

35 PFF, §§ 60 e 61, p. 154; GPZ, p. 338 - grifos do original.

36 EC, p. 35 ; WC, p. 38.

37 EC, p. 35-36; WC, p. 38.

38 PFF, § 63, p. 154; GPZ, p. 339.

39 PFF, § 64, p. 164; GPZ, p. 339. Que o pensar seja uma conversa interior do indivíduo consigo mesmo, já o afirmara Platão: "Pensamento e discurso são, pois, a mesma coisa, salvo que é ao diálogo interior e insonoro [áneu phonés] da alma consigo mesma [tés psykhés pròs autén] que chamamos pensamento" ("Sofista", 263e. Trad. bras. Jorge Paleikat e João Cruz Costa. São Paulo: Abril Cultural, 1972. - Os pensadores, em cotejamento com a edição italiana da Grandi Tascabili Economici Newton, 1997). O específico da afirmação feuerbachiana está em que não ocorre aí um diálogo sem sons (ou um raciocínio sem sensibilidade, como o diz o mesmo Platão no "Fédon", 65c). Ao contrário, é pela existência sensível e pela relação afetiva (logo, efetiva) dos homens uns com os outros que, pela linguagem sensível, pode ocorrer o pensamento no indivíduo: "Apenas pela comunicação, apenas a partir da conversação do homem com o homem brotam as ideias. Não é sozinho, mas apenas a dois se chega aos conceitos, à razão em geral. [...] a comunidade do homem com o homem é o primeiro princípio e critério da verdade e da universalidade" (PFF, § 42, p. 144; GPZ, § 42, p. 324). É por isso que, para Feuerbach, ao pensar, a alma não está isolada do corpo e das outras almas numa relação fechada consigo mesma (insonora, insensível), mas sim numa relação genérica (sonora, sensível) interior. 
essentidade da essência-gênero do homem, o é justamente assim porque a relação $\mathrm{Eu}-\mathrm{Tu}$ se constitui de uma relação sensível, afetiva, passional. O sensível que a nova filosofia reconhece como o real, pois exterior e oposto ao pensamento, é o sensível enquanto condição humano-genérica, posta como relação padecente do homem com o outro homem e, por meio deste, com os objetos sensíveis que lhes estão opostos. Se um objeto somente me é acessível mediante o outro homem, assim o é porque, enquanto objeto, se constitui de uma objetivação humano-genérica no estrito sentido de uma objetivação na e da relação Eu-Tu. Não se trata apenas de uma objetivação de essentidades humano-genéricas abstratas existentes em mim e que, por isso, encontrariam sua objetivação através de mim, estando eu numa relação sensível-afetiva com outro homem. Bem diversamente, o objeto sensível é uma objetivação de uma essentidade genérica que, precisamente enquanto tal, assim se constitui e assim se apresenta na própria relação afetiva constituída no encontro de Eu e Tu. É o outro o que, antes de tudo, se me opõe e me obriga a sair de mim enquanto ser pensante, abstrato, exigindo que eu me exteriorize sensivelmente, pela presença imediata-sensível dele, presença esta que se impõe e se comunica aos meus sentidos. Por isso, este primeiro objeto, esta primeira e fundamental objetivação genérica pela qual me constituo como essência-gênero, o Tu, é a mediação pela qual todo e qualquer outro objeto se me torna possível; e, assim, todo e qualquer objeto se constitui como objetivação da essência-gênero efetiva, in actu, que me torno pela relação com o outro. O Tu é a mediação imediata pela qual os objetos se constituem e se apresentam para mim como objetivações imediatas mediadas (e mediadas justamente pelo outro homem, pelos outros homens).

O projeto filosófico feuerbachiano, ao reivindicar um fundamento sensível, resulta não apenas numa nova posição ontológica, mas também na possibilidade de uma nova posição ética baseada na passividade sensível e, inseparavelmente, no conceito de essência-gênero, concepção esta exposta no plexo Eu-Tu. Entretanto, ele não chegou a desenvolver essa possibilidade, chegando apenas a formulá-la na forma de uma política. ${ }^{40}$ Importante, nesse âmbito, é justamente Feuerbach compreender a imediatidade sensível como

40 Cf. Feuerbach, 2002c. Talvez o não desenvolvimento dessa possibilidade se explique pelas próprias dificuldades de uma ética da passividade, coisa que, contudo, no final do século XX, o lituano Emanuel Lévinas vai tentar levar à frente, referindo-se explicitamente ao materialismo, cuja "verdade eterna" 
resultado já de uma mediação genérica, na qual o Tu já está implicado pela afecção, pela linguagem e, em seguida, pelo pensamento. A mais imediata lida com objetos é objetivação das essentidades genéricas que constituem o $\mathrm{Eu}$; por isso mesmo, enquanto genéricas, essas essentidades são mediadas pela relação com o $\mathrm{Tu}$, de modo que o próprio Eu se constitui da relação Eu-Tu. Não apenas o pensamento e a vontade contêm essa mediação genérica, mas também a contém a imediatidade sensível, pois é nesta e a partir desta que o Eu se põe numa relação com o Tu, relação que, afetiva, torna possível a linguagem e o pensamento; mas os possibilita porque ela mesma é o lugar imediato da mediação, uma imediatidade atravessada, pois posta, pela mediação genérica a que o Tu sempre conduz o Eu.

\section{Referências}

FEUERBACH, L. "Zur Kritik der Hegelshen Philosophie”. In: Gesammelte Werke. B. 9: Kleine Schriften II (1839-1846). Berlin: Akademie Verlag, 1970a.

"Vorläufige Thesen zur Reformation der Philosophie". In: Gesammelte Werke. B. 9: Kleine Schriften II (1839-1846). Berlin: Akademie Verlag, 1970b.

. "Grundsätze der Philosophie der Zukunft". In: Gesammelte Werke. B. 9: Kleine Schriften II (1839-1846). Berlin: Akademie Verlag, 1970c.

Leipzig: Reclam, 1976.

. "Geschichte der neuern Philosophie von Bacon bis Spinoza".

. "Teses provisórias para a reforma da filosofia". Tradução portuguesa de Artur Morão. Lisboa: Edições 70, 2002a.

. "Princípios da filosofia do futuro". Tradução portuguesa de Artur Morão. Lisboa: Edições 70, 2002b.

. "Necessidade de uma reforma da filosofia". In: Princípios da

filosofia do futuro. Tradução portuguesa de Artur Morão. Lisboa: Edições 70, 2002c.

. "Das Wesen des Christentums". Stuttgart: Philipp Reclam, 2005a.

. "Para a crítica da filosofia de Hegel". In: Filosofia da sensibilidade.

Escritos (1839-1846). Tradução portuguesa de Adriana Veríssimo Serrão. Lisboa: Centro de Filosofia da Universidade de Lisboa, 2005b.

. "Princípios da filosofia do futuro". Tradução portuguesa de Adriana

Veríssimo Serrão. Lisboa: Centro de Filosofia da Universidade de Lisboa, 2005c.

. "A essência do cristianismo". Tradução brasileira de José da Silva

Brandão. Petrópolis, RJ: Vozes, 2007. 
MARX, K. "Teses sobre Feuerbach" [1845]. In: Marx, K., Engels, F. A ideologia alemã. São Paulo: Editora Moraes, 1984.

"Manuscritos econômico-filosóficos". Tradução brasileira de Jesus Ranieri. São Paulo: Boitempo Editorial, 2004.

PLATÃO. "Sofista". Tradução brasileira de Jorge Paleikat e João Cruz Costa. São Paulo: Abril Cultural, 1972a. Os pensadores.

. "Fédon". Tradução brasileira de Jorge Paleikat e João Cruz Costa. São

Paulo: Abril Cultural, 1972b. Os pensadores. 